\title{
PENGARUH KECERDASAN EMOSIONAL DAN MOTIVASI KARYAWAN TERHADAP KINERJA KARYAWAN BANK MANDIRI CABANG JAMBI DR. SUTOMO
}

\author{
Merina Nindi Putri \\ Magister Manajemen, Universitas Jambi \\ Email : mermerinn199@gmail.com
}

\begin{abstract}
Abstrak
Penelitian ini ini bertujuan Pengujian untuk menganalisis pengaruh kecerdasan emosional terhadap kinerja karyawan Bank Mandiri Cabang Jambi Dr Sutomo, untuk menganalisis pengaruh motivasi karyawan terhadap kinerja karyawan Bank Mandiri Cabang Jambi Dr Sutomo dan untuk menganalisis pengaruh kecerdasan emosional dan motivasi karyawan secara bersama-sama terhadap kinerja karyawan Bank Mandiri Cabang Jambi Dr Sutomo. Data yang digunakan dalam penelitian ini adalah data primer yang diperoleh dari survey dengan menggunakan kuisioner. Jumlah Sampel yang digunakan dalam penelitian ini adalah sebanyak 56 karyawan Bank Mandiri Cabang Jambi Dr Sutomo. Metode analisis yang digunakan adalah analisis regresi linear berganda. Hasil penelitian menunjukkan bahwa : 1) Total skor variabel kecerdasan emosional karyawan Bank Mandiri Cabang Jambi Dr Sutomo adalah sebesar 1348 yang pada tingkatan yang cukup baik, sementara tanggapan responden motivasi kerja karyawan Bank Mandiri Cabang Jambi Dr Sutomo masih berada pada tingkatan yang cukup baik, dengan nilai total skor sebesar 1564, hal yang sama juga terjadi pada variabel Kinerja dengan nilai total skor 1561 yang pada tingkatan yang cukup baik. 2) Secara bersama-sama kecerdasan emosional dan motivasi kerja mampu mempengaruhi kinerja karyawan sebesar 0,409 atau sebesar 40,9 persen, sementara sisanya sebesar 59,1 persen dipengaruhi variabel lainnya yang tidak diteliti dalam penelitian ini. Dengan koefisien korelasi sebesar 0,639 menunjukkan bahwa hubungan antara kecerdasan emosional dan motivasi kerja secara langsung sangat kuat.
\end{abstract}

Key Word: Kecerdasan Emosional, Motivasi dan Kinerja

\begin{abstract}
This study aims to test to analyze the effect of emotional intelligence on the performance of the employees of Bank Mandiri Branch Jambi, Dr. Sutomo, to analyze the effect of employee motivation on employee performance at Bank Mandiri Branch Jambi, Dr. Sutomo, to analyze the effect of emotional intelligence and employee motivation together on the employee performance of Bank Mandiri Branch Jambi, Dr. Sutomo. The data used in this study are primary data obtained from a survey using a questionnaire. The number of samples used in this study were 56 employees of Bank Mandiri Jambi Branch Dr Sutomo. The analytical method used is multiple linear regression analysis. The results showed that: 1) The total score of the emotional intelligence variable of the employees of Bank Mandiri Jambi Branch, Dr Sutomo, was 1348 which was at a fairly good level, while the responses of respondents' work motivation of employees of Bank Mandiri Jambi Branch Dr Sutomo were still at a fairly good level, with a total score of 1564, the same thing happened to the Performance variable with a total score of 1561 which was at a fairly good level. 2) Together emotional intelligence and work motivation are able to influence employee performance by 0.409 or 40.9 percent, while the remaining 59.1
\end{abstract}




\section{Jurnal Manajemen Terapan dan Keuangan (Mankeu) Vol. 10 No. 01, April 2021 P-ISSN: 2252-8636, E-ISSN: 2685-9424}

percent is influenced by other variables not examined in this study. With a correlation coefficient of 0.639, it shows that the relationship between emotional intelligence and work motivation is very strong directly.

Key Word: Emotional Intelligence, Motivation and Performance

\section{PENDAHULUAN}

Beberapa faktor yang dapat mendorong peningkatan kinerja adalah adanya kecerdasan emosional dan motivasi dari karyawan. Kecerdasan emosional yang kurang optimal dapat terlihat dari gambaran belum adanya kesadaran baik secara organisasi maupun individu karyawan untuk melaksanakan tugas dengan sungguh-sungguh dan mengharapkan imbalan. Pekerjaan dilakukan secara terpaksa dan masih terdapatnya karyawan yang bekerja dengan perintah, sehingga bila terjadi permasalahan dalam melaksanakan pekerjaan tidak mampu mengambil inisiatif dalam memecahkan masalah.

Kecerdasan emosional pada dasarnya merupakan kecakapan pribadi, yang meliputi kesadaran diri dan kemampuan diri. Ketidakmampuan karyawan dalam menimbulkan kesadaran dalam bekerja akan membuat pekerjaan tidak dapat diselesaikan sesuai dengan rencana dan standar yang diminta. Kecerdasan emosional juga memiliki arti kecakapan sosial. Artinya karyawan dituntut untuk memiliki keempatian terhadap keadaan organisasi dan memberikan sumbangan kepada organisasi melalui keterampilan individu. Kurang optimalnya kemampuan ini pada gilirannya memberikan gambaran masih belum optimalnya kecerdasan emosional karyawan.

Di samping kecerdasan emosional karyawan sangat penting dalam menunjang kinerja adalah motivasi. Karyawan yang memiliki motivasi yang tinggi terhadap pekerjaan akan mendorong mereka bekerja lebih giat dan penuh tanggungjawab. Motivasi dan kecerdasan yang kurang optimal pada gilirannya akan menyebabkan kinerja karyawan juga tidak optimal.

Berdasarkan uraian di atas, dapat disimpulkan bahwa terdapat satu faktor besar yang akan mempengaruhi kepuasan kerja yaitu kecerdasan emosional dan motivasi yang terdiri dari kesesuaian antara nilai-nilai individu dengan pekerjaannya, sedangkan faktor lingkungan meliputi kinerja karyawan. Peneliti berpendapat bahwa faktor tersebut secara bersama-sama memberikan pengaruh yang bermakna terhadap kepuasan kerja. Selain itu, peneliti memperkirakan bahwa faktor individu pada organisasi memberikan pengaruh yang lebih besar terhadap kepuasan kerja dan kinerja karyawan .

Berdasarkan pada latar belakang tersebut, maka penulis tertarik melakukan penelitian dalam bentuk tesis dengan judul : Pengaruh Kecerdasan emosional dan Motivasi Karyawan Terhadap Kinerja Karyawan Bank Mandiri Cabang Jambi Dr Sutomo.

Berdasarkan fakta dan analisis di atas, maka dapat dirumuskan masalah pokok dari penelitian ini adalah :

1. Bagaimana gambaran kecerdasan emosional, motivasi kerja dan kinerja karyawan Bank Mandiri Cabang Jambi Dr Sutomo?

2. Berapa besar pengaruh kecerdasan emosional terhadap kinerja karyawan Bank Mandiri Cabang Jambi Dr Sutomo?

3. Berapa besar pengaruh motivasi karyawan terhadap kinerja karyawan Bank Mandiri Cabang Jambi Dr Sutomo?

4. Berapa besar pengaruh kecerdasan emosional dan motivasi karyawan secara Bersamasama terhadap kinerja Karyawan Bank Mandiri Cabang Jambi Dr Sutomo? 


\section{METODE PENELITIAN}

Untuk menjawab permasalahan maka digunakan model analisis regresi berganda, yaitu melalui program SPSS versi 22.00. model yang digunakan adalah :

$Y=\beta_{0}+\beta_{1} X_{1}+\beta_{2} X_{2}+e$

Dimana :

Y $\quad=$ Kinerja

$\beta_{0} \quad=$ Konstanta

$\beta_{1-2} \quad=$ Koefisien variabel independen terhadap Kinerja

$\mathrm{X}_{1} \quad=$ Kecerdasan Emosional

$\mathrm{X}_{2} \quad=$ Motivasi Kerja

$\mathrm{e} \quad=$ Faktor pengganggu

\section{HASIL DAN PEMBAHASAN}

\section{Profil Responden}

\section{Umur}

Untuk melihat keadaan responden menurut kelompok umur dapat dilihat pada tabel berikut ini :

Tabel 1 Kriteria Responden Berdasarkan Kelompok Umur

\begin{tabular}{cccc}
\hline No & Umur & Frekuensi & Persentase \\
\hline 1 & $21-26$ & 5 & 8,93 \\
2 & $27-32$ & 22 & 39,29 \\
3 & $33-38$ & 15 & 26,79 \\
4 & $39-44$ & 12 & 21,43 \\
5 & $45-50$ & 2 & 3,57 \\
Jumlah & & 80 & 100,0 \\
\hline
\end{tabular}

Sumber : Diolah dari data primer

Dari tabel di atas tergambar bahwa proporsi responden terbesar adalah berada pada kelompok umur antara 27-32 tahun, yaitu sebanyak 22 responden atau sebesar 39,29 persen dari total responden. Hal ini dapat menjadi indikator penting bahwa sebagian besar responden adalah memiliki tingkat mobilitas yang tinggi untuk melakukan kegiatan yang produktif.

Jumlah terkecil responden berada pada kelomok umur antara 45-50 tahun, yaitu sebanyak 2 responden atau sebesar 3,57 persen, hal ini memberikan gambaran bahwa mereka adalah karyawan yang sudah memiliki masa kerja yang tinggi. Secara rata-rata umur resonden adalah 35 tahun. Umur ini berada rentang yang masih sangat produktif untuk melakukan berbagai aktivitas kerja.

\section{Jenis kelamin}

Jenis kelamin dapat mencerminkan aktivitas yang dilakukan. Mereka yang berjenis kelamin laki-laki pada dasarnya memiliki mobilitas dan aktivitas yang lebih tinggi bila dibandingkan dengan perempuan. Namun demikian tidaklah selamanya demikian, karena kadang-kadang ada juga perempuan yang memiliki mobilitas dan aktivitas yang lebih tinggi bila dibandingkan dengan kaum laki-laki. Untuk lebih jelasnya proporsi responden menurut jenis kelamin dapat dilihat pada tabel berikut: 
Tabel 2.Distribusi Frekuensi Responden Menurut jenis kelamin

\begin{tabular}{ccc}
\hline Jenis kelamin & Frekuensi & Persentase $(\%)$ \\
\hline Laki-Laki & 35 & 62,50 \\
Perempuan & 21 & 37,50 \\
Jumlah & 56 & 100.00 \\
\hline
\end{tabular}

Sumber : Diolah dari data primer

Dari tabel di atas terlihat bahwa sebagian besar responden adalah berjenis kelamin laki-laki, yaitu sebanyak 35 responden atau sebesar 62,50 persen dari total responden dan hanya 21 responden yang berjenis kelamin perempuan atau sebesar 37,50 persen.

\section{Status Perkawinan}

Status perkawinan turut menjadi salah satu ukuran kematangan seseorang. Secara teori mereka yang telah menikah memiliki kematangan dalam berfikir dan bertindak dibandingkan mereka yang belum menikah. Adapun status responden menurut status pernikahan adalah sebagai berikut :

Tabel 3. Distribusi Frekuensi Responden Menurut Status Perkawinan

\begin{tabular}{lcc}
\hline \multicolumn{1}{c}{ Umur } & Frekuensi & Persentase $(\%)$ \\
\hline Belum Menikah & 9 & 16,07 \\
Menikah & 46 & 82,14 \\
Duda/Janda & 1 & 1,79 \\
Jumlah & 56 & 100.00 \\
\hline
\end{tabular}

Sumber : Diolah dari data primer

Dari tabel di atas tergambar bahwa sebagian responden telah berkeluarga, yaitu sebanyak 46 responden atau sebesar 82,14 persen. Hal ini memberikan gambaran bahwa dengan melakukan mobilitas tinggi dari responden menunjukkan bahwa mereka memiliki tanggungan keluarga yang harus dipenuhi kebutuhannya. Satu orang berstatus duda atau janda atau sebesar 1,79 persen dari total responden dan 9 orang responden belum menikah atau sebesar 16,07 persen.

\section{Masa Kerja}

Lamanya masa kerja dapat mempengaruhi kematangan seseorang dalam bekerja, biasanya mereka yang sudah memiliki masa kerja yang tinggi memiliki keterampilan dan kemampuan yang lebih baik.

Untuk lebih jelasnya keadaan masa kerja responden dapat dilihat pada tabel berikut ini :

Tabel .4 Frekuensi Responden Dirinci Menurut Masa Kerja

\begin{tabular}{ccc}
\hline Jumlah anggota Keluarga & Frekuensi & $\begin{array}{c}\text { Persentase } \\
(\%)\end{array}$ \\
\hline $1-2$ & 1 & 1,79 \\
$3-4$ & 4 & 7,14 \\
$5-6$ & 6 & 10,71 \\
$7-8$ & 13 & 23,31 \\
\hline
\end{tabular}




\begin{tabular}{ccc}
\hline $9-10$ & 12 & 21,43 \\
$11-12$ & 3 & 5,36 \\
$13-14$ & 2 & 3,57 \\
$>15$ & 15 & 26,97 \\
\hline Jumlah & 56 & 100 \\
\hline
\end{tabular}

Sumber : Diolah dari data primer

Berdasarkan tabel di atas tergambar bahwa sebagian besar responden memiliki masa kerja di atas 15 tahun, yaitu sebanyak 15 orang atau sebesar 26,97 persen. Masa kerja responden ini sudah cukup berpengalaman dalam melaksanakan tugas, sehingga diharapkan dapat mengatasai berbagai tekanan dan masalah yang timbul dalam pekerjaan.

\section{Pembahasan}

\section{Gambaran Variabel Kecerdasan emosional}

Hasil akumulasi tanggapan responden menunjukkan bahwa kecerdasan emosional karyawan Bank Mandiri Cabang Jambi Dr Sutomo masih belum memuaskan, dengan nilai total skor sebesar 1348 maka skor ini berada pada rentang 962 - 1257 atau berada pada tingkatan yang cukup baik. Hal ini menunjukkan bahwa karyawan masih memiliki kecedasan emosional yang masih tertata cukup baik dalam melakukan pekerjaan.

Apabila diperhatikan jawaban responden perindikator diperoleh hasil bahwa pada dimensi kesadaran diri diperoleh nilai rata-rata skor sebesar 3,42 atau berada pada tingkatan yang sudah baik, Hal ini menunjukkan bahwa secara sadar karyawan Bank Mandiri Cabang Jambi Dr Sutomo memiliki kesadaran yang baik untuk melakukan dan menyelesaikan pekerjaan yang dibebankan kepadanya. Kesadaran yang muncul dalam diri karyawan tidak terlepas dari kemampuan karyawan untuk memahami fungsi dirinya dalam organisasi, sehingga pada dimensi ini dapat disimpulkan bahwa kesadaran diri karyawan Bank Mandiri Cabang Jambi Dr Sutomo sudah berjalan baik.

Indikator pengaturan diri diperoleh nilai rata-rata skor sebesar 3,16 atau berada pada tingkatan yang cukup baik. Rentang yang cukup baik belumlah dapat dikategorikan sudah tahap yang baik, karena pada level ini karyawan sebagian besar kurang memiliki pengaturan diri atau dengan kata lain biasa saja. Penyebabnya tentu berkaitan dengan kurangnya kemampuan dan kemauan karyawan untuk mengelola diri mereka sendiri dalam bekerja dan menempatkan diri dalam organisasi.

Indikator ke tiga yang berkaitan dengan kecerdasan emosional adalah motivasi diri. Motivasi diri sangat penting sebagai gerbang kesuksesan untuk memacu prestasi. Semakin baik kemampuan diri karyawan dalam memotivasi dirinya sendiri maka akan semakin baik kemampuan yang akan ditunjukkannya, dengan nilai rata-rata skor sebesar 3,22 menunjukkan bahwa kemampuan memotivasi diri karyawan masih biasa-biasa saja velum pada kategori yang baik.

Indikator lainnya yang digunakan untuk mengukut variabel kecerdasan emosional karyawan Bank Mandiri Cabang Jambi Dr Sutomo adalah keempatian. Keempatian sangat penting dalam meningkatkan rasa kesetiakawanan dalam suatu organisasi. Semakin baik sikap keempatian yang ditunjukkan karyawan terhadap rekan kerjanya maka akan semakin berarti sikap-sikap sosial yang berkembang dalam organisasi. Berdasarkan hasil penelitian diperoleh nilai rata-rata skor indikator keempatian adalah sebesar 3,11. Nilai ini masih berada pada tingkatan yang biasa-biasa saja, artinya sikap keempatian karyawan Bank Mandiri Cabang Jambi Dr Sutomo belum pada katageori yang baik. 


\section{Jurnal Manajemen Terapan dan Keuangan (Mankeu) Vol. 10 No. 01, April 2021 P-ISSN: 2252-8636, E-ISSN: 2685-9424}

Indikator kelima berkaitan dengan keterampilan sosial dan personal. Setiap pekerjaan memiliki tantangan dan konsekwensi. Untuk meminimalkan kesalahan dan kekeliruan dalam bekerja maka diperlukan keterampilan sosial dan personal. Karyawan yang memiliki keterampilan sosial dan personal bukan hanya akan mampu menjawab tantangan saja akan tetapi lebih jauh akan mampu menemukan metode-metode pemecahan masalah yang lebih efektif dan efisien, sehingga tidak memberikan dampak yang berakibat buruk. Berdasarkan hasil penelitian diperoleh nilai skor-rata-rata indikator keterampilan sosial dan personal adalah sebesar 3,12. Nilai ini masih berada pada rentang yang cukup baik. Artinya keterampilan sosial dan personal karyawan Bank Mandiri Cabang Jambi Dr Sutomo secara umum biasa-biasa-saja. Hal ini mengingatkan kepada segenap jajaran Bank Mandiri Cabang Jambi Dr Sutomo untuk meningkatkan kemampuan sosial dan personal karyawan.

\section{Motivasi kerja}

Hasil akumulasi tanggapan responden menunjukkan bahwa motivasi kerja karyawan Bank Mandiri Cabang Jambi Dr Sutomo masih belum memuaskan atau masih berada pada tingkatan yang cukup baik, dengan nilai total skor 1564 maka skor ini berada pada rentang 1344 - 1791 atau berada pada tingkatan yang cukup baik. Hal ini menunjukkan bahwa diperlukan upaya yang lebih untuk meningkatkan motivasi kerja karyawan pada tingkatan yang optimal.

Indikator pertama berkaitan dengan keterpautan dan keterikatan Secara emosional dengan organisasi. Semakin baik ikatan moril dengan organsiasi maka akan semakin sadar karyawan bahwa organisasi memerlukan dirinya untuk beraktivitas dan dirinyapun menyadari bahwa dirinya memerlukan organisasi untuk beraktivitas. Keterpautan dan keterikatan menjadi pijakan yang kuat bagi organisasi untuk saling membutuhkan dan saling memahmi pentingnya prinsip mitra kerja dalam organisasi. Dengan nilai 2,74 menunjukkan bahwa pada indiaktor pertama masih berada pada tingkatan yang cukup baik. Indikator yang cukup baik belumlah dapat dikatakan bahwa karyawan sudah memiliki keterpautan dan keterikatan dalam bekerja. Pada kenyataannya masih banyak karyawan yang tidak merasa nyaman bekerja dilingkup organisasi mereka. Hal ini menjadi gambaran penting bahwa untuk meningkatkan keterpautan dan keterikatan karyawan diperlukan dorongan yang lebih besar pada karyawan untuk bekerja secara nyaman dalam organisasi.

Indikator ke dua yang digunakan untuk mengukur motivasi kerja karyawan Bank Mandiri Cabang Jambi Dr Sutomo adalah mengenali organisasi. Mengenali organisasi maksudnya adalah kemampuan karyawan untuk mengenali berbagai potensi, kelemahan, kelebihan, keunggulan dan kekuatan yang dimiliki oleh Bank Mandiri Cabang Jambi Dr Sutomo. Kemampuan mengenali organisasi pada gilirannya akan membantu karyawan dalam menempatkan dirinya dalam organisasi. Dengan nilai indikator rata-rata sebesar 2,85 menunjukkan bahwa indikator mengenali organisasi karyawan masih berada dalam kategori yang cukup, belum pada tingkatan yang baik. Hal ini harus diperhatikan organsiasi, karena bagaimanapun karyawan yang mengenali organisasi akan memiliki kemampuan yang baik dalam membantu seluruh aktivitas organisasi

Indikator ke tiga berkaitan dengan pelibatan diri dalam setiap kegiatan organisasi. Karyawan yang memiliki motivasi yang kuat terhadap pekerjaannya biasanya memiliki keinginan yang kuat untuk terus beraktivitas membantu setiap aktivitas kerja organisasi. Dukungan dengan melibatkan diri dalam setiap kegiatan organisasi pada dasarnya wujud keinginan yang kuat dari karyawan untuk memajukan organisasi. Berdasarkan hasil 


\section{Jurnal Manajemen Terapan dan Keuangan (Mankeu) Vol. 10 No. 01, April 2021 P-ISSN: 2252-8636, E-ISSN: 2685-9424}

perhitungan diperoleh nilai skor rata-rata indikator melibatkan diri adalah sebesar 2,88. Nilai ini berada pada rentang yang cukup baik, nilai ini bukanlah pada tingkatan yang optimal, tetapi harus lebih diperjuangkan agar setiap karyawan memiliki kepedulian terhadap pekerjaan atau aktivitas organisasi.

Indikator ke empat berkaitan dengan kesadaran pada sisi pengrobanan organsiasi. Kesadaran pada sisi organsiasi maksudnya adalah bahwa organsasi telah memberikan kepercayaan dan kesempatan kepada setiap karyawan dengan menjadi bagian penting dalam organisasi. Adanya pengorbanan tersebut harus direspon secara baik oleh karyawan. Karyawan yang tahu berterima kasih dan memiliki etika moral yang baik akan memegang teguh nama baik organisasi. Berdasarkan hasil penelitian diperoleh nilai rata-rata indikator sisi pengrobanan organsiasi sebesar 2,82 atau berada pada tingkatan yang cukup baik. Rentang yang cukup baik menunjukkan bahwa pemahaman karyawan terhadap sisi pengorbanan organisasi belum optimal dan harus ditingkatkan secara terus menerus.

Indikator kelima yang digunakan untuk mengukur motivasi kerja karyawan adalah kesadaran di dalam organisasi. Kesadaran di dalam organisasi adalah kemauan untuk memahami organisasi dan posisi setiap karyawan dalam organisasi. Kesadaran untuk mampu memposisikan diri dalam organisasi secara baik bukan hanya akan mendukung dan membantu organisasi dalam mengejar visi dan misinya, akan tetapi lebih akan membantu menciptakan suasana kerja yang kondusif aman dan nyaman, sehingga aktivitas organisasi akan berjalan lebih optimal. Berdasarkan hasil penelitian diperoleh nilai ratarata skor indikator kesadaran dalam organisasi adalah sebesar 2,65 atau berada pada rentang yang cukup baik. Tingkatan ini belumlah dapat dikatakan baik, tetapi harus terus dibina sehingga terbina kesadaran diri dalam organisasi yang lebih baik dan lebih bermanfaat bagi kepentingan organisasi.

Indikator ke enam berkaitan dengan kewajiban untuk melanjutkan kekaryaan organisasi. Berdasarkan hasil penelitian diperoleh nilai-rata skor sebesar 2,78 atau berada pada tingkatan yang cukup. Hasil ini memperlihatkan bahwa rasa wajib untuk melanjutkan kekaryaan organisasi masih belum optimal. Pada indikator ke tujuh yang berkaitan dengan kepedulian untuk tetap tinggal bersama organisasi juga direspon karyawan dalam kategori yang cukup baik, dengan nilai rata-rata skor sebesar 2,86

\section{Kinerja}

Kinerja karyawan Bank Mandiri Cabang Jambi Dr Sutomo masih belum memuaskan, dengan nilai total skor sebesar 1561 maka skor ini berada pada rentang 1156,8 - 1511,1 atau berada pada tingkatan yang sudah baik.

Secara umum apabila dilihat dari indikator yang ditampilkan juga masih tergolong cukup baik. Indikator pertama yang digunakan untuk mengukur variabel Kinerja karyawan adalah kualitas sesuai standar kerja. Nilai rata-rata yang diperoleh dari hasil penelitian adalah sebesar 2,93. Nilai ini berada pada kategori yang cukup baik. Gambaran nilai ratarata ini menunjukkan bahwa belum semua karyawan memahami pentingnya kualitas kerja yang sesuai standar kerja. Karyawan yang efektif dalam bekerja adalah karyawan yang menyadari penting kualitas memperhatikan standar kerja.

Indikator ke dua yang digunakan untuk mengukur Kinerja karyawan adalah adanya pengakuan kualitas kerja dari penilai indepdent. Pengakuan hasil kerja dari penilai independent sangat penting karena lebih objektif. Secara rata-rata nilai indikator kedua adalah sebesar 3,16 yang berada pada kategori cukup baik. Artinya belum sepenuhnya karyawan menyadari pentingnya penilaian dari tim independent dalam menilai hasil kerja karyawan . 


\section{Jurnal Manajemen Terapan dan Keuangan (Mankeu) Vol. 10 No. 01, April 2021 P-ISSN: 2252-8636, E-ISSN: 2685-9424}

Indikator ke tiga berkaitan erat dengan kemampuan karyawan dalam menyelesaikan pekerjaan yang sesuai dengan jadwal kerja, dengan nilai rata-rata skor sebesar 3,11 indikator ini berada pada kategori yang cukup baik. Artinya selama ini tidak semua pekerjaan dapat diselesaikan sesuai dengan jadwal, gambaran nilai rata-rata yang berada pada rentang menengah belum mencerminkan hasil yang baik.

Indikator keempat berkaitan dengan pekerjaan berjalan dengan efisien. Rata-rata nilai skor adalah sebesar 3,32 atau berada pada rentang yang cukup baik. Gambaran ini menunjukkan bahwa tidak semua pekerjaan berjalan secara efisien. Artinya organisasi dituntut untuk lebih efisien dalam bekerja. Pekerjaan yang dilakukan secara efeisien tidak hanya akan menghemat anggaran, akan tetapi lebih jauh akan mampu lebih mengoptimalkan waktu kerja sehingga tidak terbuang secara sia-sia.

Indikator kelima adalah memiliki inisiatif untuk menyelesaikan pekerjaan. Nilai ratarata skor adalah sebesar 2,92. Nilai ini berada pada kategori yang cukup baik. Adakalanya banyak sekali hambatan dan gangguan dalam menyelesaikan setiap pekerjaan, sehingga menyebabkan pekerjaan tidak dapat diselesaikan. Dalam kondisi seperti ini seorang karyawan dituntut untuk memiliki inisiatif dalam menyelesaikan pekerjaan. Nilai yang berada pada kategori cukup baik bukanlah hasil yang optimal, hal ini memberikan gambaran hanya sebagian saja dari karyawan yang memiliki inisiatif mampu menyelesaikan pekerjaan.

Indikator ke enam berkaitan dengan membantu kesulitan rekan kerja, dengan nilai rata-rata skor sebesar 3,38 menunjukkan indikator ini berada pada rentang yang cukup baik. Rentang yang cukup baik bukanlah menunjukkan hasil yang optimal, akan tetapi menunjukkan bahwa masih banyak karyawan yang tidak memiliki kepedulian untuk membantu kesulitan rekan kerja lainnya.

Indikator ke tujuh berkaitan dengan pekerjaan sesuai dengan ahlinya. Pekerjaan yang sesuai dengan ahlinya memiliki makna bahwa orang yang mengerjakan tugas tersebut memiliki keterampilan dan keahlian untuk menyelesaikan pekerjaan tersebut. Berdasarkan hasil penelitian diperoleh nilai rata-rata skor sebesar 3,30 atau berada pada tingkatan yang cukup baik. Artinya masih terdapat juga karyawan yang bekerja belum sesuai dengan keahlian yang dimilikinya. Hal ini sangat mengganggu ritme kerja organisasi, karena bagaimanapun juga memerlukan waktu yang lebih lama untuk dapat menyelesaikan pekerjaan tersebut.

Indikator ke delapan berkaitan dengan memiliki tekad yang kuat dalam bekerja. Nilai rata-rata skor indikator ini adalah sebesar 3,26. Nilai ini berada pada rentang yang cukup baik. Artinya tidak semua karyawan memiliki tekad yang kuat dalam bekerja. Tekad yang kuat dalam bekerja sangat penting untuk mendukung Kinerja secara organisasi. Tekad yang kuat dapat mengalahkan segalan tantangan dan hambatan yang dimiliki dalam bekerja. Orang yang memiliki tekad yang kuat akan bekerja dengan segala kekuatan yang dimilikinya.

Indikator ke sembilan berkaitan erat denga kemampuan dalam menjalin koordinasi denan bidang lain. Nilai rata-rata skor adalah sebesar 3,15 atau berada pada tingkatan yang cukup baik. Nilai ini juga bukan berada pada rentang yang optimal. Artinya masih banyak terdapat karyawan yang belum mampu bekerja dengan koordinasi dengan bidang lainnya. Padahal bekerja secara koordinasi dengan bidang lainnya sangat penting agar pekerjaan dapat dilakukan dengan lebih efektif dan efisien.

Indikator ke sepuluh berkaitan erat dengan memiliki keterampilan dalam mengkomunikasikan permasalahan. Berdasarkan hasil penelitian diperoleh nilai rata-rata skor sebesar 3,27 atau berada pada tingkatan yang cukup baik. Artinya belum semua 
karyawan memiliki keterampilan dalam mengkomunikasi permasalahan kerja dengan baik. Indikator ini menjadi sangat penting karena setiap masalah dapat dipecahkan dengan baik apabila mampu dikomunikasi dengan pihak-pihak lain yang memiliki kompeten.

Indikator ke sepuluh yang digunakan untuk mengukur Kinerja karyawan adalah memiliki keterampilan menjalin pihak stakeholder. Bank Mandiri Cabang Jambi Dr Sutomo selama ini memiliki mitra pendukung kerja. Kemampuan menjalin komunikasi dengan mitra pendukung sangat penting untuk menjaga soliditas dan mencegah terjadinya kecurigaan dalam sistem kerja. Dengan nilai rata-rata skor indikator sebesar 2,91 menunjukkan tingkatan yang cukup baik. Nilai ini belumlah berada pada kategori yang optimal.

\section{Pengaruh Kecerdasan Emosional Terhadap Kinerja Karyawan Bank Mandiri Cabang Jambi Dr Sutomo}

Pengaruh langsung kecerdasan emosional terhadap Kinerja karyawan Bank Mandiri Cabang Jambi Dr Sutomo adalah sebesar 0,241 atau sebesar 24,1 persen. Namun demikian pengaruh tidak langsung kecerdasan emosional melalui motivasi kerja adalah sebesar 0,340, dan pengaruh variabel kecerdasan emosional melalui variabel profesionalitas kerja terhadap Kinerja lebih besar yaitu sebesar 0,553 atau sebesar 55,3 persen. Pengaruh total kecerdasan emosional terhadap Kinerja karyawan melalui profesionalitas karyawan diperoleh sebesar 0,581 atau sebesar 58,1 persen. Hal ini berarti kecerdasan emosional dengan dukungan motivasi kerja dan profesionalitas dapat meningkatkan Kinerja karyawan sebesar 21,7 persen.

Kecerdasan emosional adalah kesanggupan yang dibutuhkan seseorang dalam melaksanakan tugas atau pekerjaannya dengan penuh rasa tanggung jawab sesuai dengan tujuan yang ditetapkan. Bagi seorang karyawan menghadapi berbagai permasalahan yang berkaitan dengan perkembangan aktivitas pekerjaa merupakan suatu fenomena dan tantangan sehari-hari. Dari aktivitas tersebut akan lahir berbagai permasalahan apabila tidak ditangani secara arif, aktif, reaktif dan kreatif dan bijaksana justru akan memberikan dampak yang buruk terhadap pekerjaan. Permasalahan yang dihadapi seorang karyawan yang memiliki kecerdasan emosional, biasanya senantiasa berusaha mencari solusi dengan strategi yang tepat agar tidak menimbulkan dampak yang kurang baik, bagi dirinya dan Bank Mandiri Cabang Jambi Dr Sutomo sebagai suatu institusi. Karena mereka menyadari bahwa keberhasilan akan sangat tergantung pengenalan dan pemahaman kecerdasan emosional pada pekerjaan. Tanpa memiliki kecerdasan emosional kerja akan sangat sulit bagi seorang karyawan untuk mampu menjalankan atau menyelesaikan tugasnya tersebut

Kecerdasan emosional menemukan pemecahan masalah tersebut akan lahir bila kecerdasan emosional kerja mendorong karyawan untuk mengoptimalkan kecerdasan emosionalnya mencari solusi setiap masalah yang dihadapinya. Hal ini akan bertolak belakang pada seorang karyawan yang tidak memiliki kecerdasan emosional terhadap pekerjaan, setiap permasalahan yang timbul akan dihadapi dengan kaku dan cenderung bersifat dogmatis, sehingga terkesan karyawan yang tidak memiliki kecerdasan emosional akan cenderung menyelesaikan masalah dengan sikap yang kurang bijaksana dan tidak memberi jalan keluar dengan penyelesaian masalah yang elegan.

Kecerdasan emosional pada dasarnya merupakan suatu keterampilan dan keahlian, yang merupakan gambaran kecerdasan dan keterampilan seseorang untuk senantiasa memegang teguh tanggungjawab yang telah diputuskannya. Orang yang memiliki kecerdasan emosional adalah orang yang memiliki yang dapat dipercaya dalam 
menjalankan tugas atau kewajibannya. Kecerdasan emosional karyawan menuntut pula kemauan untuk berperan secara aktif dalam kegiatan atau mendukung kemajuan organisasi. Peran aktif ini akan mendorong seorang karyawan untuk mencurahkan segala kecerdasan emosional yang dimilikinya secara optimal demi sebuah idealisme dan tanggungjawab yang dipilihnya, hal ini jelas akan memberikan dampak terhadap peningkatan Kinerja mereka.

Karyawan biasanya sadar bahwa kewajiban merupakan suatu sikap kerelaan hati dari tugas yang dipikul sebagai seorang karyawan. Ia harus memiliki kerelaan dalam menstrafer ilmu yang dimilikinya. Sadar kewajiban merupakan bentuk dari pengabdian dan ia merupakan pendorong utama untuk melakukan kegiatannyanya. Seorang yang memiliki kecerdasan emosional yang tinggi biasanya memiliki ketegasan dalam sikap dan ketegasan dalam bertindak. Karena ia menyadari bahwa setiap pekerjaan yang dilakukannya akan menimbulkan resiko, untuk itu agar setiap permasalahan dapat selesai maka diperlukan ketegasan sikap dalam mengambil keputusan dan bertindak.

Adanya kecerdasan emosional yang kuat dari karyawan akan mendorong mereka memiliki sikap loyalitas terhadap pekerjaannya dan menjunjung nilai-nilai semangat kerja yang tercermin dalam profesionalitas yang kuat untuk melakukan pekerjaan. Kecerdasan emosional yang tinggi kuat pada gilirannya akan memberikan arah terhadap usaha mencapai tujuan yang ada dalam pekerjaan dan menjadikannya sebagai sumber aspirasi untuk berkreasi meningkatkan Kinerja dengan semangat pengabdian.

Hasil penelitian ini sejalan dengan penelitian yang pernah dilakukan oleh Fatmasari dan Budiono (2017), Iha Haryani Hatta dan Widarto Rachbini (2017) serta Mahardhika (2016) yang menyatakan terdapat pengaruh yang positif antara Kecerdasan emosional dengan kinerja. Hasil penelitian ini memperkuat penelitian Kristof (1996)

\section{Pengaruh Motivasi Kerja Terhadap Kinerja Karyawan Bank Mandiri Cabang Jambi Dr Sutomo}

Pengaruh motivasi kerja terhadap Kinerja karyawan Bank Mandiri Cabang Jambi Dr Sutomo adalah sebesar 0,482 atau sebesar 48,2 persen. Namun demikian pengaruh tidak langsung motivasi kerja melalui profesionalitas kerja terhadap kerja lebih besar yaitu sebesar 0,614 atau sebesar 61,4 persen. Pengaruh total motivasi kerja terhadap Kinerja karyawan melalui kecerdasan emosional karyawan diperoleh sebesar 0,5318 atau sebesar 53,18 persen. Hal ini berarti motivasi kerja dengan dukungan profesionalitas dapat meningkatkan Kinerja karyawan sebesar 61,4 persen

Motivasi kerja adalah kecakapan perilaku dan perbuatan untuk mentaati semua peraturan dan norma-norma sosial yang berlaku, guna menciptakan lingkungan kerja yang tertib dan berdayaguna yang tinggi. Seseorang yang memiliki motivasi kerja akan senantiasa bertindak dengan motivasi kerja yang tinggi, berhati-hati dalam bertindak dan bersikap dan senantiasa bersikap tegas dalam menjalankan tugas dan kewajibannya. Seorang karyawan yang motivasi kerja senantiasa mengatur semua kegiatannya dengan terencana, memiliki target dalam menyelesaikan pekerjaan dan senantiasa bersikap jujur dan terbuka dalam melakukan tugas dan kewajibannya

Dengan kesadaran dan kesediaan seorang karyawan untuk menerapkan motivasi kerja akan mendorong mereka bekerja dan bertindak sesuai dengan aturan-aturan yang berlaku. Apabila motivasi kerja tetap terpelihara maka etos kerja mereka akan meningkat yang pada gilirannya akan mendorong mereka berprestasi secara lebih optimal. 
Motivasi kerja berarti seorang karyawan taat terhadap segala ketentuan atau peraturan yang telah dibuat organisasi. Ketaatan terhadap aturan atau ketentuan yang berlaku dalam organisasi merupakan kesadaran yang timbul dari diri seorang karyawan manakala ia memasuki lingkungan organisasi dan menjadi bagian darinya. Di sini ia menyadari segala konsekwensi terhadap aturan yang dibuat oleh organisasi.

Motivasi kerja juga dapat mengandung makna bahwa seorang karyawan mengerti sistem aturan individu dan organisasi yang harus dipenuhi yang berlaku dalam sebuah lingkungan kerja. Aturan yang berlaku dalam sebuah lingkungan kerja dipergunakan sebagai acuan dari sistem kerja secara individu. Memahami sistem aturan yang berlaku dalam organisasi berarti seorang karyawan berusaha ingin mengetahui aturan kerja yang berlaku dan memahaminya serta menerapkannya dalam menyelesaikan setiap tugas yang dibebankan kepadanya.

Motivasi kerja juga dapat berarti bahwa seorang karyawan juga memahami makna berlakunya sistem kerja dalam lingkungan kerjanya. Sistem kerja dalam lingkungan kerja bertujuan agar semua kegiatan masing-masing individu dapat di organisasi secara rapi dan memiliki tingkat koordinasi yang tinggi dengan rekan kerjanya.

Motivasi kerja juga dapat berarti memiliki makna bahwa seorang karyawan dituntut untuk bekerja dengan kesunggguhan hati. Pilihan menjadi bagian dari lingkungan kerja menuntut bahwa seseorang memang harus memiliki kesungguhan hati dalam menyelesaikan semua tugas yang dibebankan kepadanya. Kesungguhan hati sebagai cerminan bagi seorang karyawan apakah sadar akan tugas dan kewajibannya sebagai bagian dari anggota organisasi.

Motivasi kerja seorang karyawan memiliki makna kesadaran diri. Pada gilirannya semua ketentuan yang berlaku akan sia-sia apabila seorang karyawan tidak memiliki kesadaran tinggi untuk mematuhi segala aturan yang berlaku. Kesadaran diri disini sebagai cerminan pribadi seorang karyawan apakah dapat menjadi bagian dari organsisasi atau tidak.

Hasil penelitian ini ternyata sejalan dengan penelitian Yunita Sari dan M. Al Musadieq (2018) serta penelitian Diska Amalia (2017) yang menyatakan bahwa motivasi memiliki pengaruh yang positif dan signifikan terhadap kinerja karyawan.

\section{Pengaruh Kecerdasan Emosional Dan Motivasi Kerja Terhadap Kinerja Karyawan Bank Mandiri Cabang Jambi Dr Sutomo}

Secara bersama-sama kecerdasan emosional dan motivasi kerja mampu mempengaruhi Kinerja karyawan sebesar 0,409 atau sebesar 40,9 persen, sementara sisanya sebesar 59,1 persen dipengaruhi variabel lainnya yang tidak diteliti dalam penelitian ini. Dengan koefisien korelasi sebesar 0,639 menunjukkan bahwa hubungan antara kecerdasan emosional dan motivasi kerja secara langsung sangat kuat. Berdasarkan hasil pengujian diperoleh angka pengganda pengaruh kecerdasan emosional dan motivasi kerja secara bersama-sama diperoleh sebesar 0,723 . Angka ini lebih tinggi bila dilakukan pengujian secara parsial.

Jika hasil analisis statistik dan deskriptif ini dihubungkan dengan analisis verifikatif seperti yang diuraikan diatas, nampak jelas bahwa semakin banyak Karyawan Bank Mandiri Cabang Jambi Dr Sutomo yang melakukan upaya-upaya kearah Peningkatan kecerdasan emosional dan motivasi kerja, tentunya akan sangat berpengaruh pada peningkatan Kinerja Bank Mandiri Cabang Jambi Dr Sutomo secara keseluruhan. Hal ini dapat dibuktikan dengan adanya angka koeifisien determinasi yang cukup tinggi. 
Angka koeifisien determinasi tersebut tentunya memberikan makna bahwa bahwa semakin banyak upaya - upaya yang dilakukan oleh Karyawan Bank Mandiri Cabang Jambi Dr Sutomo untuk meningkatkan kecerdasan emosional mereka dan peningkatan motivasi kerja karyawan pada akhirnya juga akan berdampak pada peningkatan Kinerja Bank Mandiri Cabang Jambi Dr Sutomo.

\section{SIMPULAN DAN SARAN}

\section{Simpulan}

1. Variabel kecerdasan emosional karyawan Bank Mandiri Cabang Jambi Dr Sutomo berada pada tingkatan yang cukup baik, begitu juga dengan motivasi kerja karyawan Bank Mandiri Cabang Jambi Dr Sutomo masih berada pada tingkatan yang cukup baik, hal yang sama juga terjadi pada variabel kinerja berada pada tingkatan yang cukup.

2. Secara parsial kecerdasan emosional berpengaruh positif dan signifikan terhadap kinerja karyawan Bank Mandiri Cabang Jambi Dr Sutomo.

3. Secara parsial kecerdasan emosional berpengaruh positif dan signifikan terhadap kinerja karyawan Bank Mandiri Cabang Jambi Dr Sutomo.

4. Secara bersama-sama kecerdasan emosional dan motivasi kerja mampu mempengaruhi kinerja karyawan sebesar 0,409 atau sebesar 40,9 persen, sementara sisanya sebesar 59,1 persen dipengaruhi variabel lainnya yang tidak diteliti dalam penelitian ini. Dengan koefisien korelasi sebesar 0,639 menunjukkan bahwa hubungan antara kecerdasan emosional dan motivasi kerja secara langsung sangat kuat

\section{Saran}

Mengingat variabel motivasi kerja lebih dominan dalam mempengaruhi kinerja karyawan, maka sebaiknya peneliti berikutnya perlu meneliti variabel-variabel lain untuk melihat keabsahan hasil penelitian ini dan mengkombinasikan dengan variabel dependent lain seperti kepuasan kerja, kreativitas ataupun kualitas kerja dan produktivitas kerja.

Mengingat variabel kecerdasan emosional belum menunjukkan keadaan yang belum optimal maka sebaiknya pimpinan Bank Mandiri Cabang Jambi Dr Sutomo perlu meningkatkan kecerdasan emosional terutama yang berkaitan dengan kemampuan mengendalikan diri dan menjaga emosi diri.

Untuk meningkatkan motivasi karyawan maka pimpinan Bank Mandiri Cabang Jambi Dr Sutomo perlu memberikan dorongan baik berupa insentif maupun dalam bentuk penghargaan.

Pimpinan dan seluruh jajaran Bank Mandiri Cabang Jambi Dr Sutomo diharapkan mampu secara konsisten dan penuh tanggungjawab untuk meningkatkan hasil kerja baik secara kualitas maupun secara kuantitas

\section{DAFTAR PUSTAKA}

Ashkenas et al. (2005, Relationship Between Person Organization Fit and Performance Indices of Public Hospitals Affiliated With Qazvin University of Medical Science in Iran. Journals bmsu. 2: 59-62.

Ayman Sawaf, 2012, Perilaku SUmber Daya Manusia, Penerbit Salemba Empat, Jakarta. Bocal (2013), 2013, Performing In Organization, terjemahan Erlangga, Jakarta.

Dessler, Gary. 2013, Human Resourrce Management. Terjemahan Benyamin Molan, Jakarta: PT. Prehalindo.

Goleman, Daniel 2011, Human Resourrce Management. Terjemahan Benyamin Molan, PT. Prehalindo, Jakarta. 
Fatmasari dan Budiono, 2017, Pengaruh Kecerdasan emosional dan Gaya Kepemimpinan terhadap terhadap Kinerja Pegawai pada Dinas Lingkungan Hidup Kota Palembang, Jurnal FEBI Unsri.

Gomes, Andre 2014, Organisai daan Manajemen : Perilaku Struktural dan proses, Cetakan ke empat, penerbit Erlangga, Jakarta.

Handoko, T.Hani, 2014, Manajemen Sumber Daya Manusia, BP- FE UGM, Yogyakarta 2016, Manajemen, BP- FE UGM, Yogyakarta.

Harsey, Blanchard and Johnson, 2002, Human Resources Management New Jersey, Prentice Hall International, Inc.

Indra WIjaya, 2000, Mengukir Prestasi : Panduan Menjadi Profesional. Misaka Galiza, Jakarta.

Jajang Wahyudi, 2011, Pengaruh Gaya Kepemimpinan dan Disiplin Kerja Terhadap Kinerja Karyawan Pada Badan Perencanaan Pembangunan dan Penanaman Modal (Bapemdal) Kabupaten Tanjung Jabung Barat, Tesis, Jambi.

Manullang, Hendri. 2010, Pengembangan Sumber Daya Manusia, Penerbit Rineka CIpta, Jakarta.

Mangkunegara, Anwar Prabu Mangkunegara, 2014, Manajemen Sumber Daya Manusia, PT. Remaja Rosda Karya, Bandung.

Mas'ud, Fuad. 2014. Survai Diagnosis Organisasional: Konsep dan Aplikasi.Badan Penerbit Uniiversitas Diponegoro. Semarang.

Mahardika (2014, Model Person-Organisation Fit (P-O Fit Model) terhadap Kepuasan Kerja, Komitmen Organisasional dan Kinerja Karyawan. Jurnal Bisnis dan Ekonomi (JBE) Maret 2010.

Masi \&Robert A.Cooke, 2012, Effects Transformational Leadershipon Subordinate Motivation, Empowering Norms, and Organizational Productivity ( Ralp J. Masi \&Robert A.Cooke, 2000, International Journal.

Naomi Ellemers, Dick De Gilder, S. Alexander Haslam, 2013, Motivating Individuals and Groups at Work : a Social Identity Perspectiveon Leadership and Group (Naomi Ellemers, Dick De Gilder, S. Alexander Haslam, International Journal.

Nurjanah 2016, Pengaruh Gaya Kepemimpinan dan Kecerdasan emosional terhadap Motivasi Organisasi dalam meningkatkan Kinerja Karyawan (studi pada biro Lingkup Departemen Pertanian, Tesis.

Phitchik. 2013. Effects of work values on job choicedecisions. Journal of Applied Psychology.

Pangabean, Mutiara, 2011, Pengembangan Sumber Daya Manusia, Penerbit PT. Rineka Cipta, Jakarta.

Robins, Stephen P, 2010, Perilaku Organisasi, Terjemahan Erlangga, Edisi III, Penerbit PT. Erlangga, Jakarta.

Reeve, 2011. The ASA framework: an update. Personnel Psychology.

Ruky.S. Ahmad 2010 Sistem Manajemen Kinerja. Jakarta: Gramedia Pustaka Utama, Jakarta.

Reni Devita, 2010, Pengaruh Kecerdasan EMosional dan Disiplin Kerja terhadap Motivasi dan Implementasinya pada Kinerja Pegawai Universitas Syiah Kuala Banda Aceh, , Tesis.

Rivai, Veithzal, 2014, Manajemen dan Motivasi, Balai Aksara, Jakarta. 